\title{
ANALISIS PERBEDAAN LAPORAN KEUANGAN TAHUNAN PADA PERUSAHAAN LQ45 SEBELUM DAN SAAT PANDEMI COVID-19
}

\author{
${ }^{a}$ Ari Nurul Fatimah, ${ }^{b}$ Diah Agustina Prihastiwi, cLena Islamiyatun \\ abc Universitas Tidar \\ ari.nurul.fatimah@untidar.ac.id
}

\author{
\begin{tabular}{l|l|l} 
Received: October & Accepted : November & Published: December
\end{tabular}
}

\section{ABSTRAK}

\begin{abstract}
Analisis Perbedaan Laporan keuangan Tahunan pada Perusahaan LQ45 Sebelum dan Saat Pandemi Covid-19. Pandemi Covid-19 di tahun 2020 telah memberikan pengaruh pada sektor ekonomi khususnya pada perusahaan-perusahaan go public di Indonesia. Kinerja keuangan perusahaan mnejadi fokus pada penelitian ini. Penelitian ini bertujuan untuk mnganalisis perbedaan kinerja keuangan perusahaan yang bergabung di Indeks LQ45 sebelum pandemi Covid-19 dan pada saat pandemi Covid-19. Data yang digunakan dalam peenelitian ini yaitu laporan keuangan tahunan di Tahun 2019 dan Tahun 2020 seluruh perusahaan di Indeks LQ45. Variabel yang digunakan dalam pengukuran kinerja keuangan ini yaitu current ratio, debt equity ratio, total asset turnover, dan debt equity ratio. Metode penelitian ini menggunakan uji beda yang diawali dengan uji normalitas terlebih dahulu, kemudian dilanjutkan dengan dua alat uji beda yaitu paired sample $t$-test dan Wilcoxon signes rank test. Hasil dari uji beda pada penelitian ini yang dihasilkan adalah keempat variabel independent yang digunakan terdapat perbedaan nilai dari current ratio, debt equity ratio, total asset turnover, dan debt equity ratio. Mayoritas perusahaan yang tergabung pada Indeks LQ45 kinerja keuanganya masih lebih baik di masa sebelum pandemi daripada saat terjadinya pandemi. hal tersebut ditunjukkan dengan nilai current ratio, debt equity ratio, total asset turnover, dan debt equity ratio tahun 2020 lebih kecil daripada di tahun 2019.
\end{abstract}

Kata kunci: Covid-19, kinerja keuangan, uji beda

\section{ABSTRACT}

Analysis of Differences in Annual Financial Statements for LQ45 Companies Before and During the Covid-19 Pandemic. The Covid-19 pandemic in 2020 has had an impact on the economic sector, especially on publicly traded companies in Indonesia. The company's financial performance is the focus of this research. This study aims to analyze the differences in the financial performance of companies that joined the LQ45 Index before the Covid-19 pandemic and during the Covid-19 pandemic. The data used in this research are the annual financial statements in 2019 and 2020 of all companies in the LQ45 Index. The variables used in measuring financial performance are the current ratio, debt equity ratio, total asset turnover, and debt equity ratio. This research method uses a different test that begins with the normality test first, then continues with two different test tools, namely the paired sample t-test and the Wilcoxon signes rank test. The results of the different tests in this study are the four independent variables used, there are differences in the values of the current ratio, debt equity ratio, total asset turnover, and debt equity ratio. The majority of companies that are members of the LQ45 Index have better financial performance in the pre-pandemic period than during the pandemic. this is indicated by the value of the current ratio, debt equity ratio, total asset turnover, and debt equity ratio in 2020 which is smaller than in 2019.

Keywords: Covid-19, financial performance, different test 


\section{PENDAHULUAN}

Merebaknya Virus Covid-19 di dunia membawa dampak serius pada bidang Kesehatan, ekonomi, transportasi, dan bidang lainnya di berbagai industri dan wilayah. Mobilitas penduduk menurun akibat kebijakan karantina yang menyebabkan daya beli melemah dan ekonomi stagnan. Di tingkat makro, pandemic covid-19 menyebabkan resesi global dan ekonomi dalam kondisi lemah. Di tingkat perusahaan, wabah covid-19 mempengaruhi pasar saham, kinerja perusahaan di berbagai industry. Oleh karena itu, pentingnya untuk mengevalasi dampak wabah covid-19 terhadap kinerja perusahaan di masa ekonomi sulit (Shen et al., 2020).

Dampak jangka Panjang dari pandemic ini sangat sulit untuk diperkirakan karena berada di tengah krisis. Kajian tentang dampak sosial, ekonomi, dan budaya dari pandemic ini sangat terbatas. Studi literatur yang ada menganalisis tentang dampak yang berkaitan dengan peristiwa di masalalu umumnya menunjukkan adanya penurunan dan pengembalian asset selama dan setelah pandemi. Beberapa bisnis pengecer akan menghadapi kesulitan dalam jangka pendek. Akan tetapi. Bisnis lain seperti bisnis yang berbasis rantai pasokan, manufaktur, Kesehatan akan menghadapi masalah seperti penurunan permintaan, pengurangan arus kas, pendapatan penjualan, ketersediaan tenaga kerja, dan siklus pemasaran (Rababah et al., 2020). Pemerintah telah menganalisis bahwa Krisis ekonomi akibat pandemic covid-19 akan berdampak pada penurunan laba dan kinerja keuangan di berbagai jenis usaha. Oleh karena itu, penerapan pajak insentif merupakan Langkah awal pemerintah untu melakukan penyelamatan ekonomi pada sektor yang paling berpengaruh terutama sektor riil yang menyerap banyak tenaga kerja. Selain itu krisis ekonomi juga berdampak pada penurunan penjualan produk yang dihasilkan oleh perusahaan. Penurunan penjualan akan berdampak pada kinerja keuangan (Devi et al., 2020).

Indonesia merupakan salah satu negara yang terdampak pandemic covid-19. Wabah tersebut telah mengubah aspek kehidupan terutama di bidang ekonomi. Beberapa harga saham di Indonesia telah mengalami penurunan karena adanya kondisi fundamental perusahaan serta kondisi ekonomi negara. Shen et al. (2020) melakukan penelitian pada dampak pandemic covid-19 pada kinerja perusahaan. Hasilnya yaitu wabah covid-19 memiliki dampak negatif yang signifikan terhadap kinerja perusahaan China yang terdaftar. Industry yang terkena dampak seperti transportasi, pariwisata, dan penjualan industry lainnya terjadi penurunan kinerja yang signifikan pada kuartal I tahun 2020. Pada penelitian Violandani (2021), pandemic covid-19 berdampak pada kinerja keuangan perusahaan pada indeks LQ45. Penelitiannya menganalisis tentang kinerja keuangan sebelum dan sesudah pandemi bahwa ada perbedaan rasio keuangan yang terjadi. Kumala et al. (2021) juga neliti tentang pengaruh pandemic covid-19 terhadap laporan keuangan triwulan pada perusahaan LQ45. Penelitian tersebut menggunakan rasio keuangan sebagai variabelnya. Hasilnya yaitu varibael current ratio dan total ratio antara sebelum dan sesudah pandemic covid-19 terjadi perbedaan yang signifikan. Dari penjelasan di atas, peneliti tertarik untuk melakukan penelitian pada perbedaan kinerja keuangan laporan keuangan tahunan pada perusahaan LQ45 sebelum dan saat pandemi covid-19. Laporan keuangan yang akan dipakai yaitu tahun 2019 dan 2020. Pada bagian selanjutnya akan disajikan tentang kajian literatur kemudian diikuti dengan metode, hasil, dan kesimpulan

\section{KAJIAN LITERATUR}

Pada bab kajian literatur ini akan dibahas empat literatur yang berhubungan dengan penelitian ini yaitu tentang penyebaran virus Covid-19, laporan keuangan, kinerja keuangan perusahaan, dan rasio keuangan. selain itu, pada bab ini juga disajikan beberapa penelitian terdahulu yang terkait dengan penelitian ini. 


\section{Penyebaran Virus Covid-19}

Pandemic Covid-19 pertama kali muncul di akhir Desember 2019 di Wuhan yang disebabkan oleh virus corona. Virus ini dapat menginfeksi manusia dan hewan yang menyerang saluran pernapasan dengan gejala awal flu. Pada 11 Maret 2020, WHO mengumumkan pandemic Covid-19 sebagai pandemic global. Sejalan dengan pengumuman dari WHO tersebut, penyebaran Covid-19 sangat cepat sehingga tidak hanya menyebabkan krisis Kesehatan namun telah berkembang menjadi krisis ekonomi yang mendalam di seluruh dunia (Nguyen et al., 2021).

Pada 2 Maret 2020, Covif-19 masuk ke Indonesia. Untuk mengantisipasi dan membatasi penyebaran yang lebih luas, Pemerintah Indonesia mengambil Tindakan dengan mengeluarkan berbagai kebijakan seperti bekerja dari rumah, menjaga jarak, dan Pembatasan Sosial Berskala Besar (PSBB) (Rahayu \& Muharam, 2021).

\section{Laporan keuangan}

Bentuk pertanggungjawaban administrasi perusahaan kepada public yaitu adanya transparansi pada laporan keuangan perusahaan. Hal tersebut menjadi kesadaran perusahaan dalam melakukan tata Kelola yang baik dengan memberikan pengguna akses informasi terhadap kinerja keuangan perusahaan. (Devi et al., 2020) (Sunita devi). Laporan keuangan menyajikan suatu informasi mengenai posisi keuangan dan kinerja suatu entitas.

Tujuan dari laporan keuangan yaitu sebagai dasar untuk mengalami kenaikan dan penurunan pada kinerja perusahaan. Laporan keuangan juga dapat memprediksi apakah perusahaan mengalami kesulitan keuangan atau tidak (Setyaningrum et al., 2020)

\section{Kinerja keuangan perusahaan}

kinerja keuangan perusahaan merupakan bentuk pencapaian perusahaan dalam aspek keuangan yang berkaitan dengan pendapatan dan biaya operasional secara keseluruhan seperti struktur hutang, asset, dan hasil investasi. Kinerja keuangan tidak terbatas pada pembahasan satu periode saja, karena pemangku kepentingan akan memperhatikan setiap perubahan kinerja keuangan perusahaan. Perubahan tren tersebut terjadi pada laporan keuangan yaitu laba rugi, arus kas, maupun posisi keuangan. Kinerja keuangan perusahaan akan bergantung pada kebijakan, strategi, dan Tindakan yang diterapkan oleh manajemen untuk mewujudkan tujuan dari organisasi. Kinerja keuangan dapat diukur melalui analisis laporan keuangan (Devi et al., 2020). Kinerja keuangan perusahaan dapat dilihat dari laporan keuangan tahunan yang disusun oleh perusahaan. Laporan keuangan tahunan tersebut dapat dibandingkan dengan laporan keuangan tahuntahun yang lalu dengan melihat perkembangan yang terjadi yaitu kenaikan atau penurunan suatu konsistensi perusahaan tersebut. Kinerja keuangan perusahaan dapat dilihat dari rasio-rasio keuangan. Melalui analisis rasio-rasio keuangan tersebut kondisi keuangan perusahaan dapat diketahui pada waktu tertentu (Wijayani, 2017).

\section{Rasio Keuangan}

Rasio keuangan menjadi faktor penting dalam pengukuran kinerja keuangan perusahaan. Rasio keuangan merupakan indeks yang menghubungkan antara angka akuntansi yang dilakukan antara pos satu dengan yang lainnya. Menurut Munawir (2014), ada empat rasio keuangan untuk menilai kinerja keuangan perusahaan:

\section{Rasio likuiditas}

Rasio likuiditas digunakan untuk mengukur kemampuan perusahaan dalam melunasi kewajiban jangka pendek perusahaan yang segera jatuh tempo. Likuiditas tersebut diartikan sebagai tingkat kelikuiditan sebuah perusahaan apabila mampu melunasi kewajiban jangka pendek saat jatuh tempo. Jika perusahaan tidak likuid berarti perusahaan tidak mampu untuk melunasi kewajibannya. Tujuan dari analisis rasio likuiditas ini memberikan fungsi bagi pihak eksternal untuk dasar pengambilan keputusan dalam hal pengelolaan keuangan. Rasio likuiditas dapat dijadikan sebagai pengendali pihakmanajemen pada ketersediaan 
asset yaitu kas untuk memenuhi kewajibannya. (Violandani, 2021). Dalam penelitian ini, rasio likuiditas diukur dengan menggunakan Current Rasio yaitu perbandingan antara asset lancar dengan utang lancar.

2. Rasio solvabilitas

Rasio solvabilitas merupakan rasio keuangan yang digunakan untuk mengetahui kemampuan perusahaan dalam pemenuhan kewajibannya. Semakin tinggi tingkat rasio solvabilitasnya maka semakin besar pula aset perusahaan dapat didanai oleh hutang dan semakin besar pula resiko default perusahaan. Jika perusahaan memiliki rasio solvabilitas yang rendah, perusahaan akan mendapatkan peringkat yang semakin baik pula (Pinanditha \& Suryantini, 2016). Dalam penelitian ini, rasio solvabilitas diukur dengan menggunakan Debt Equity Rasio yaitu perbandingan antara total hutang dengan total ekuitas.

3. Rasio aktivitas

Rasio aktivitas yaitu rasio yang menunjukkan perusahaan mampu dalam melaksanakan kegiatannya terutama dalam penggunaan asset yang dimiliki secara efektif atau tidak. Rasio ini juga melihat kinerja manajemen dalam pengelolaan aktivitas perusahaan terutama dalam kefektivan dan keefisienan dalam memanfaatkan sumber daya. (Violandani, 2021) Penelitian ini mengukur rasio aktivitas tersebut dengan membandingkan penjualan dengan total asset atau sering disebut Total Asset Turnover.

\section{Rasio profitabilitas}

Rasio profitabilitas digunakan untuk mengukur kemampuan perusahaan dalam mendapatkan keuntungan dengan memperhitungkan aset atau ekuitas. Semakin tinggi rasio profitabilitas, perusahaan dinilai dapat memliki resiko gagal bayar semakin rendah (Pinanditha \& Suryantini, 2016) Pada penelitian ini rasio profitabilitas diukur dengan tingkat keuntungan dihasilkan dari ekuitas. Perhitungan tersebut membnadingkan laba dengan otoal ekuitas yang biasa disebut dengan Return On Equity.

\section{Penelitian Terdahulu}

\section{Tabel 1 \\ Penelitian Terdahulu}

\begin{tabular}{|c|c|c|}
\hline Judul \& Penulis & Metode Penelitian & Hasil \\
\hline $\begin{array}{l}\text { Pengaruh } \\
\text { Pandemi Virus } \\
\text { Covid-19 } \\
\text { Terhadap Laporan } \\
\text { Keuangan } \\
\text { Triwulan Pada } \\
\text { Perusahaan Lq-45 } \\
\text { yang Terdaftar Di } \\
\text { Bursa Efek } \\
\text { Indonesia (Kumala } \\
\text { et al., 2021), }\end{array}$ & $\begin{array}{l}\text { Sampel penelitian diambil } \\
\text { dengan menggunakan } \\
\text { metode purposive sampling. } \\
\text { Populasi dalam penelitian } \\
\text { ini adalah perusahaan LQ- } \\
45 \text { yang terdaftar di Bursa } \\
\text { Efek Indonesia (BEI) } \\
\text { periode 2019-2020, } \\
\text { sehingga populasi } \\
\text { penelitian ini berjumlah } 45 \\
\text { perusahaan. Adapun yang } \\
\text { dipilih sesuai dengan } \\
\text { kriteria sampel yang } \\
\text { ditentukan adalah } 33 \\
\text { perusahaan. Pengumpulan } \\
\text { data dilakukan dengan } \\
\text { metode dokumentasi. } \\
\text { Penelitian ini dianalisis } \\
\text { menggunakan alat analisis } \\
\text { Paired Sample T-test. }\end{array}$ & $\begin{array}{l}\text { Tidak ada perbedaan signifikan } \\
\text { variabel Current Ratio dan Debt to } \\
\text { Total Assets Ratio antara sebelum } \\
\text { dan selama pandemi covid-19. Terjadi } \\
\text { perbedaan yang signifikan Assets } \\
\text { Turnover, Return On Assets dan } \\
\text { Return On Equity antara sebelum dan } \\
\text { selama pandemi covid-19. }\end{array}$ \\
\hline Komparasi & Populasi dalam penelitian & Hasil pengujian wilcoxon signed rank \\
\hline
\end{tabular}




\begin{tabular}{|c|c|c|}
\hline $\begin{array}{lr}\text { Rasio } & \text { Keuangan } \\
\text { Sebelum } & \text { Dan } \\
\text { Selama } & \text { Pandemi } \\
\text { Covid-19 } & \text { Pada } \\
\text { Perusahaan } & \\
\text { Terbuka } & \text { yang } \\
\text { Terdaftar } & \text { Pada } \\
\text { Indeks } & \text { Lq45 } \\
\text { (Violandani, } & \text { 2021) }\end{array}$ & $\begin{array}{l}\text { ini adalah perusahaan } \\
\text { terbuka yang terdaftar } \\
\text { dalam Indeks LQ45 periode } \\
\text { Agustus 2020-Januari 2021. } \\
\text { Pengambilan sampel } \\
\text { dilakukan dengan metode } \\
\text { purposiver sampling. } \\
\text { Sehingga diperoleh } 39 \\
\text { perusahaan sebagai } \\
\text { sampel. Metode analisis } \\
\text { data yang digunakan yaitu } \\
\text { paired sample t-test dan } \\
\text { wilcoxon signed rank test, } \\
\text { yang sebelumnya dilakukan } \\
\text { uji normalitas. }\end{array}$ & $\begin{array}{l}\text { test menunjukkan bahwa terdapat } \\
\text { perbedaan pada total assets turnover } \\
\text { dan return on equity antara sebelum } \\
\text { dan selama adanya pandemi Covid- } \\
19 \text {. }\end{array}$ \\
\hline $\begin{array}{l}\text { PENGARUH } \\
\text { PANDEMI COVID- } \\
19 \text { TERHADAP } \\
\text { KINERJA } \\
\text { KEUANGAN } \\
\text { PERUSAHAAN } \\
\text { MANUFAKTUR } \\
\text { YANG } \\
\text { TERDAFTAR DI } \\
\text { BURSA EFEK } \\
\text { INDONESIA } \\
\text { (Studi Kasus Pada } \\
\text { Perusahaan } \\
\text { Manufaktur } \\
\text { Bursa di } \\
\text { Indonesia) Efek } \\
\text { (Anugrah et al., } \\
\text { n.d.) }\end{array}$ & $\begin{array}{l}\text { Metode yang digunakan } \\
\text { untuk menentukan sampel } \\
\text { menggunakan purposive } \\
\text { sampling. Terdiri dari } 175 \\
\text { perusahaan manufaktur } \\
\text { yang terdaftar di Bursa Efek } \\
\text { Indonesia (BEI) dengan } \\
\text { sampel 109. Metode } \\
\text { analisis yang digunakan } \\
\text { adalah analisis data } \\
\text { deskriptif. Uji normalitas } \\
\text { yang digunakan adalah uji } \\
\text { Kolmogorov-smirnov. Uji } \\
\text { Hipotesis menggunakan } \\
\text { Paired Sample t-test. } \\
\text { hipotetis }\end{array}$ & $\begin{array}{l}\text { Hasil pengujian pada penelitian ini } \\
\text { maka dapat disimpulkan bahwa: } \\
\text { 1. Terdapat penurunan signifikan } \\
\text { return on equity (ROE) sebelum dan } \\
\text { saat terjadinya pandemi COVID-19. } 2 \text {. } \\
\text { Tidak terdapat penurunan signifikan } \\
\text { debt to equity ratio (DER) sebelum } \\
\text { dan saat terjadinya pandemi COVID- } \\
\text { 19. } \\
\text { 3. Terdapat penurunan signifikan total } \\
\text { asset turnover (TATO) sebelum dan } \\
\text { saat terjadinya pandemi COVID-19. } \\
\text { 4. Tidak terdapat penurunan } \\
\text { signifikan current ratio (CR) sebelum } \\
\text { dan saat terjadinya pandemi COVID- } \\
\text { 19. Saran }\end{array}$ \\
\hline $\begin{array}{l}\text { IMPACT OF } \\
\text { COVID-19 ON } \\
\text { STOCK PRICES } \\
\text { AND FINANCIAL } \\
\text { PERFORMANCE } \\
\text { IN TOMPANY THE } \\
\text { COMPAN } \\
\text { (Studi pada Emiten } \\
\text { LQ 45 yang listing } \\
\text { di BEI) (Rahmani, } \\
\text { 2020) }\end{array}$ & $\begin{array}{l}\text { Penelitian ini menggunakan } \\
\text { sampel perusahaan LQ-45 } \\
\text { yang sudah menerbitkan } \\
\text { laporan keuanganya di } \\
\text { Bursa Efek Indonesia (BEI). } \\
\text { Analisis penelitian ini } \\
\text { menggunakan metode } \\
\text { regresi linier berganda } \\
\text { dengan bantuan SPSS } 25 \text {. }\end{array}$ & $\begin{array}{l}\text { Hasil dari peneltiian ini yaitu: } \\
\text { 1. Peristiwa pandemi Covid-19 di } \\
\text { Indonesia telah berdampak terhadap } \\
\text { turunnya rata-rata harga saham } \\
\text { Emiten LQ } 45 \text { di BEI } \\
\text { 2. Peristiwa pandemi Covid-19 yag } \\
\text { melanda Indonesia berdampak pada } \\
\text { menurunnya kinerja keuangan : ROA, } \\
\text { OPM emiten LQ } 45 \text { di BEI }\end{array}$ \\
\hline $\begin{array}{l}\text { The Impact of } \\
\text { COVID-19 } \\
\text { Pandemic on the } \\
\text { Financial } \\
\text { Performance of } \\
\text { Firms on the } \\
\text { Indonesia Stock } \\
\text { Exchange (Devi et } \\
\text { al., 2020) }\end{array}$ & $\begin{array}{l}\text { Sampel penilitian mencakup } \\
214 \text { perusahaan yang } \\
\text { terbagi secara proporsional } \\
\text { kedalam sembilan sektor } \\
\text { atau } 49 \text { subsektor. Analisis } \\
\text { data menggunakan } \\
\text { Wilcoxon Signed Rank } \\
\text { Test. }\end{array}$ & $\begin{array}{l}\text { Hasil dari penelitian ini yaitu } \\
\text { a.Terjadi peningkatan rasio leverage } \\
\text { dan rasio aktivitas, namun terjadi } \\
\text { penurunan rasio likuiditas dan rasio } \\
\text { profitabilitas pada perusahaan publik } \\
\text { selama masa pandemi COVID-19, } \\
\text { b .tidak terdapat perbedaan yang } \\
\text { signifikan pada rasio likuiditas dan } \\
\text { rasio leverage, namun terdapat } \\
\text { perbedaan yang signifikan pada rasio }\end{array}$ \\
\hline
\end{tabular}




\begin{tabular}{|l|l|l|}
\hline & profitabilitas dan rasio aktivitas pada \\
& perusahaan publik antara sebelum \\
dan selama pandemi COVID-19, \\
c.sektor yang mengalami peningkatan \\
rasio likuiditas, rasio profitabilitas, dan \\
rasio aktivitas adalah sektor barang \\
konsumsi, sedangkan sektor yang \\
mengalami penurunan rasio likuiditas \\
dan rasio profitabilitas adalah \\
properti, real estate dan konstruksi \\
bangunan, keuangan, perdagangan., \\
jasa, dan sektor investasi.
\end{tabular}

\section{Kerangka konseptual}

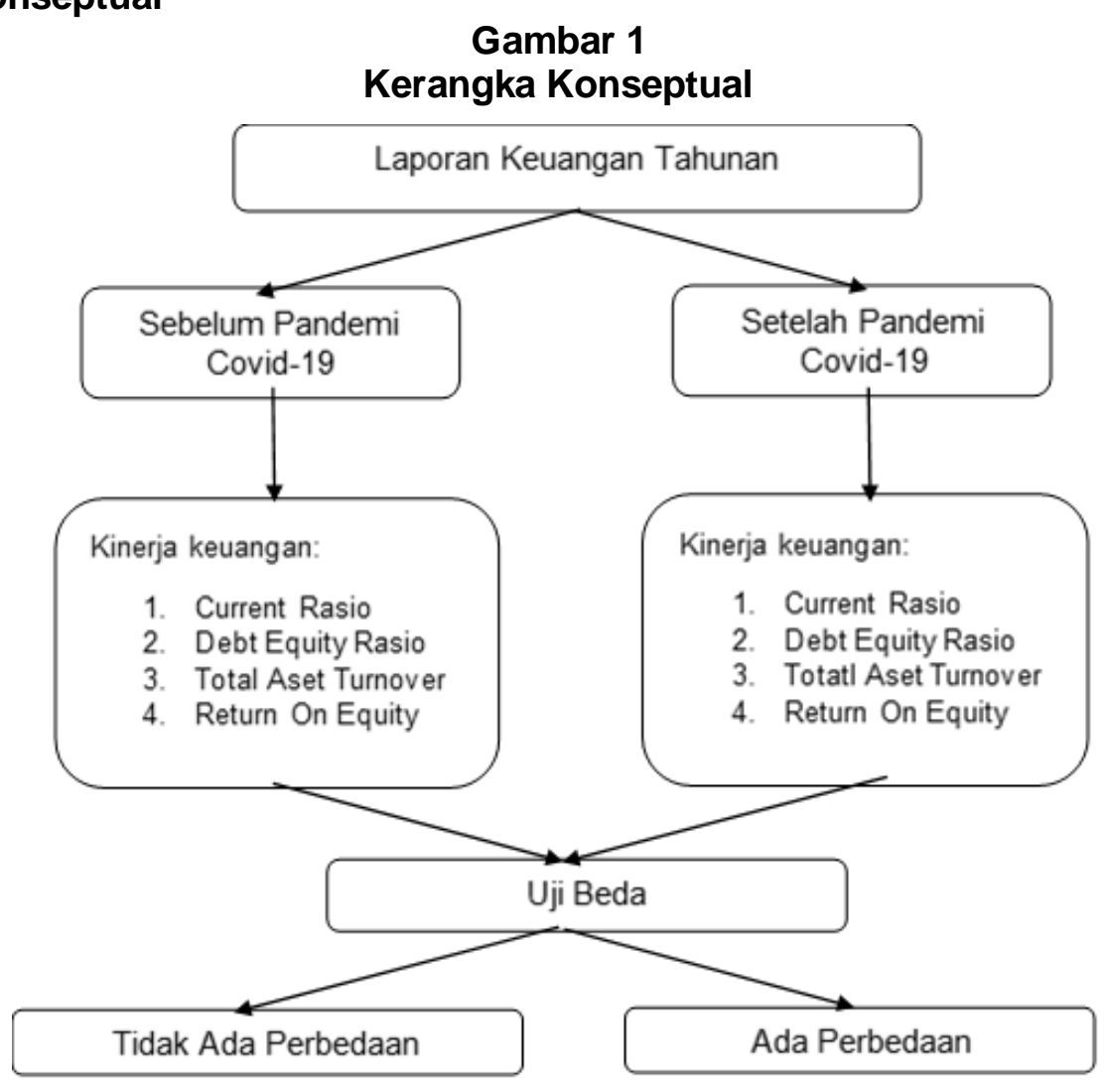

Hipotesis yang bisa diajuka dari penelitian ini yaitu:

$\mathrm{H}_{1} \quad$ : Terdapat perbedaan yang signifikan antara Current Rasio sebelum dan saat pandemi Covid-19 pada perusahaan LQ45 di Laporan Keuangan Tahunan.

$\mathrm{H}_{2} \quad$ : Terdapat perbedaan yang signifikan antara Debt Equity Rasio sebelum dan saat pandemi Covid-19 pada perusahaan LQ45 di Laporan Keuangan Tahunan.

$\mathrm{H}_{3} \quad$ :Terdapat perbedaan yang signifikan antara Total Asset Turnover sebelum dan saat pandemi Covid-19 pada perusahaan LQ45 di Laporan Keuangan Tahunan.

$\mathrm{H}_{4} \quad$ : Terdapat perbedaan yang signifikan antara Return On Equity sebelum dan saat pandemi Covid-19 pada perusahaan LQ45 di Laporan Keuangan Tahunan. 


\section{Jenis Penelitian}

\section{METODE}

Jenis penelitian ini merupakan penlitian komparatif kuantitiatif. Penelitian ini bertujuan untuk mengetahui perbedaan kinerja keuangan pada laporan keuangan tahunan di perusahaan LQ45 sebelum dan saat pandemi Covid-19.

\section{Jenis dan Sumber Data}

Data penelitian ini merupakan jenis data kuantitatif. Peneliti mengambil sumber data untuk penelitian ini yaitu dari website Busrsa Efek Indonesia. Data yang diambil yaitu seluruh laporan keuangan tahunan pada perusahaan LQ45 Tahun 2019 dan Tahun 2020.

\section{Definisi dan Pengukuran Variabel}

Variabel yang digunakan pada penelitian ini yaitu merupakan rasio keuangan perusahaan untuk mengukur kinerja keuangan perusahaan yaitu:

1. Rasio Likuiditas

Rasio ini digunkan untuk mnegetahui kemampuan perusahaan dalam membayar kewajibannya dalam jangka pendek, dirumuskan dengan:

2. Rasio Solvabilitas

$$
\text { Current Rasio :CR }=\frac{\text { Total Aset Lancar }}{\text { Total hutang lancar }}
$$

Rasio ini untuk mengetahui kemampuan perusahaan dalam pemenuhan kewajibankewajibannya yang dirumuskan dengan:

\section{Rasio Aktivitas}

$$
\text { Debt Equity Ratio : DER }=\frac{\text { Total Hutang }}{\text { Total ekuitas }}
$$

Rasio ini untuk mengetahui efektivitas dan efisien perusahaan dalam menggunakan sumber daya yang dimiliki yang dirumuskan dengan:

4. Rasio Profitabilitas

$$
\text { Total Asset Turnover : } T \text { ATO }=\frac{\text { Penjualan }}{\text { Total eset }}
$$

Rasio ini digunakan untuk mengetahui kemampuan perusahaan dalam memperoleh laba dari sisi ekuitasnya yang dirumuskan dengan:

$$
\text { Return on Equity: } R O E=\frac{\text { Laba }}{\text { Totalekuitas }}
$$

\section{Teknik Analisis Data}

Teknik analisis data pada penelitian ini yaitu statistic deskriptif menggunakan uji normalitas dan uji beda rata-rata. Uji beda yang akan digunakan yaitu paired simple test dan Wilcoxon signed rank.

\section{Uji Normalitas}

Uji normalitas dilakukanuntuk mengetahui apakah variabel penelitian terdistribusi secara normal atau tidak. Uji normalitas ini dilakukan menggunakan alat Uji KolmogrofSmirnov. Ketentuan nilai signifikansi terdistribusi normal atau tidak akan mempengaruhi uji selanjutnya. Ketentuan variabel dikatakan terdistribusi normal yaitu jika nilainya $>0,05$. Jika nilai signifikasinya normal berarti uji yang dilakukan selanjutnya yaitu menggunakan uji paired sample $t$-tes. Untuk nilai signifikansi $<0.05$, berarti nilai tersebut tidak terdistribusi normal. Langkah selanjutnya yaitu dilakukan Uji Wilcoxon Signed Rank Test.

\section{Paired Sample t-Test}

Paired t-test merupakan salah satu metode pengujian hipotesisi untuk mneguji data yang digunakan berpasangan. Data penelitian akan mendapatkan 2 perlakuan yang berbeda satu macam data. (Montolalu \& Langi, 2018). Pada penelitian ini uji yang dilakukan yaitu membandingkan kinerja keuangan melalui rasio keuangan pada laporan keuangan tahunan sebelum dan sesudah pandemic Covid-19. Uji ini digunakan pada nilai signifikan 
varibael yang telah di uji normalitasnya termasuk normal. Berikut merupakan rumus yang digunakan pada paired sample t-test:

$$
t=\frac{\mathrm{X}_{1}-\mathrm{X}_{2}}{\sqrt{\frac{S_{1}{ }^{2}}{n_{1}}+\frac{S_{2}{ }^{2}}{n_{2}}-2 r\left(\frac{S_{1}}{\sqrt{n_{1}}}\right)\left(\frac{S_{2}}{\sqrt{n_{2}}}\right)}}
$$

Keterangan:

$\mathrm{X}_{1} \quad$ : rata-rata sebelum

$\mathrm{X}_{2}$ : rata-rata selama

$S_{1} \quad$ : simpangan baku sebelum

$\mathrm{S}_{2} \quad$ : simpangan baku selama

$\mathrm{N}_{1} \quad$ : jumlah data sebelum

$\mathrm{N}_{2} \quad$ : jumlah data selama

$\mathrm{S}_{1}{ }^{2} \quad \because$ varians sebelum

$\mathrm{S}_{2}{ }^{2} \quad$ : varians selama

$r \quad$ : korealasi anatar sebelum dan selama

\section{Wilcoxon Signed Rank test}

Pengujian ini dilakukan saat uji normalitas data tidak terdistribusi normal. Pengujian ini juga digunakan untuk mengetahui perbedaan pada suatu penelitian. Namun pada uji ini ada beberapa kriteria dalam menetukan ada perbedaan atau tidak pada data penelitian. Kriterianya yaitu

a. Koefisien yang digunakan yaitu $\alpha=0,05$

b. Jika nilai Asymp Sig (2-tailed) $<0,05$, maka terdapat perbedaan

c. Jika nilai Asymp Sig (2-tailed) $>0,05$, maka tidak terdapat perbedaan

Berikut rumus yang digunakan dalam perhitungan Wilcoxon Rank Tes.

$$
Z=\frac{T-\frac{n(n+1)}{4}}{\sqrt{\frac{n(n+1)(2 n+1)}{24}}}
$$

Keterangan:

Z $\quad:$ Z score hasil perhitungan Wilcoxon signed rank test

$\mathrm{T} \quad$ : jumlah ranking positif

n : jumlah data

Hasil Penelitian

HASIL DAN PEMBAHASAN

\section{Hasil Uji Normalitas}

Berikut adalah hasil uji normalitas dari empat variabel dengan menggunakan Uji KolmogrofSmirnov untuk mengetahui kenormalitasan data.

Tabel 2

Hasil Uji Kolmogrof- Smirnov

\begin{tabular}{|l|l|l|l|l|l|l|l|l|l|}
\hline & CR2019 & CR 2020 & DER 2019 & DER 2020 & $\begin{array}{l}\text { TATO } \\
2019\end{array}$ & $\begin{array}{l}\text { TATO } \\
2020\end{array}$ & ROE2019 & ROE2020 \\
\hline $\mathrm{N}$ & 45 & 45 & 45 & 45 & 45 & 45 & 45 & 45 \\
\hline $\begin{array}{l}\text { Normal } \\
\text { parameters } \\
(\mathrm{a}, \mathrm{b})\end{array}$ & Mean & 1760.3333 & 1630.8222 & 1788.1778 & 2258.4667 & 73.6444 & 43.8222 & 175,6667 & 65,1556 \\
\hline & & & & & & & & & \\
\hline
\end{tabular}




\begin{tabular}{|l|l|l|l|l|l|l|l|l|l|}
\hline $\begin{array}{l}\text { Most } \\
\text { Extreme } \\
\text { Difference }\end{array}$ & Absolute & 0.096 & 0.069 & 0.229 & 0.256 & 0.185 & 0.167 & 0.322 & 0.316 \\
\hline & Positive & 0.096 & 0.069 & 0.229 & 0.256 & 0.185 & 0.163 & 0.322 & 0.290 \\
\hline & Negative & -0.085 & -0.065 & -0.209 & -0.240 & -0.152 & -0.167 & -0.203 & -0.316 \\
\hline & 0.096 & 0.069 & 0.229 & 0.256 & 0.185 & 0.167 & 0.322 & 0.316 \\
\hline Kolmogorov-Smirnov Z & 0.096 & $0.200^{c, d}$ & $0.000^{c}$ & $0.000^{c}$ & $0.000^{c}$ & $0.003^{c}$ & $0.000^{c}$ & $0.000^{c}$ \\
\hline
\end{tabular}

Berdasarkan tabel di atas, hasll uji Kolmogrof-Smirnov menghasilkan nilai variabel yang berbeda-beda. Jumlah data yang diolah pada penelitian ini yaitu 45 perusahaan. Variabel Current ratio menunjukkan nilai signifikansi yang sama di tahun 2019 dan tahun 2020 yaitu sebesar 0,200. Hal ini menunjukkan bahwa nilai signifikansi tersebut terdistribusi normal karena lebih besar dari 0,05 sehingga untuk pengujian selanjutnya variabel current ratio menggunakan paired sample t-test. Variabel debt equity ratio nilai signifikansi yang ditunjukkan yaitu sebebsar 0,000 pada tahun 2019 dan tahun 2020. Hal tersebut menunjukkan nilainya tidak terdistribusi normal karena kurang dari 0,05 . Untuk pengujian selanjutnya, variabel debt equity ratio menggunakan Wilcoxon signed rank test.

Selanjutnya untuk variabel total asset turnover, hasil signikansinya menunjukkan nilai 0,000 pada tahun 2019 dan 0,003 pada tahun 2020. Nilai tersebut menunjukkan bawa hasil nilai signifikansinya tidak terdistribusi normal karena lebih dari 0,05. Begitu pula dengan variabel return on equity, nilai signifikansinya menunjukkan 0,000 di tahun 2019 dan tahun 2020. Hal tersebut menunjukkan data tidak terdistribusi normal karena nilainya lebih dari 0,05 . Untuk kedua variabel tersebut yaitu total asset turnover dengan return on equity, pengujian selanjutnya menggunakan Wilcoxon signed rank test.

\section{Hasil Paired Sample t-test}

Hasil uji kolmogrov-smirnov menunjukkan bahwa dari keempat variabel yang diujikan, hanya satu variabel yang terdistribusi normal yaitu variabel current ratio. Oleh karena itu, pengujian selanjutnya variabel current ratio menggunakan paired sample t-test. Berikut adalah hasil dari paired sample t-test.

Tabel 3

Hasil Paired Sample Statistics Test Current Ratio

\begin{tabular}{|c|c|c|r|c|c|}
\hline \multicolumn{7}{|c|}{ Paired Samples Statistics } \\
\hline \multicolumn{2}{|c|}{} & Mean & N & $\begin{array}{c}\text { Std. } \\
\text { Deviation }\end{array}$ & $\begin{array}{c}\text { Std. Error } \\
\text { Mean }\end{array}$ \\
\hline \multirow{2}{*}{ Pair 1 } & CR 2019 & 1760.3333 & 45 & 1282.28282 & 191.15144 \\
\cline { 2 - 6 } & CR 2020 & 1630.8222 & 45 & 1074.90577 & 160.23749 \\
\hline
\end{tabular}

Berdasarkan tabel di atas, hasil statistic deskriptif dari paired sample t-test untuk variabel current ratio adalah dari jumlah data 45 perusahaan, rata-rata current ratio tahun 2019 nilainya lebih besar yaitu 1760,33 dibandingkan di tahun 2020 yang menunjukkan nilai 1630,82 . Selain itu standar deviasi tahun 2019 juga lebih besar nilainya yaitu 1282,28 jika dibandingkan di tahun 2020 yang nilainya 1074,90.

\section{Tabel 4}

Hasil Paired Sample Test Current Ratio

\begin{tabular}{|c|c|c|c|c|c|c|c|c|c|}
\hline \multicolumn{10}{|c|}{ Paired Samples Test } \\
\hline & & \multicolumn{5}{|c|}{ Paired Differences } & \multirow[b]{3}{*}{$t$} & \multirow[b]{3}{*}{ df } & \multirow{3}{*}{$\begin{array}{l}\text { Sig. (2- } \\
\text { tailed) }\end{array}$} \\
\hline & & \multirow[b]{2}{*}{ Mean } & \multirow{2}{*}{$\begin{array}{c}\text { Std. } \\
\text { Deviatio } \\
n\end{array}$} & \multirow{2}{*}{$\begin{array}{l}\text { Std. } \\
\text { Error } \\
\text { Mean }\end{array}$} & \multicolumn{2}{|c|}{$\begin{array}{l}95 \% \text { Confidence } \\
\text { Interval of the } \\
\text { Difference }\end{array}$} & & & \\
\hline & & & & & Lower & Upper & & & \\
\hline $\begin{array}{l}\mathrm{Pa} \\
\text { ir } \\
1\end{array}$ & $\begin{array}{l}\text { CR 2019 - CR } \\
2020\end{array}$ & $\begin{array}{r}129.511 \\
11\end{array}$ & $\begin{array}{r}634.017 \\
98\end{array}$ & $\begin{array}{r}94.513 \\
82\end{array}$ & $\begin{array}{r}- \\
60.9689 \\
8\end{array}$ & 319.99120 & $\begin{array}{r}1.37 \\
0\end{array}$ & 44 & .178 \\
\hline
\end{tabular}


Berdasarkan tabel di atas, hasil dari t hitung current ratio menunjukkan niali 1,370, degree of freedom sebesar 44 , dan nilai signifikansinya sebesar 0,178 . Nilai signifikasnsi tersebut lebih besar dari 0,05. Nilai tersebut dapat disimpulkan nilai current ratio tahun 2019 dan tahun 2020 terdapat perbedaan.

\section{Uji Wilcoxon Signed Rank Test}

Berdasarkan Uji Komolgrov-Smirnov, ketiga variabel penelitian menunjukkan nilai yang tidak terdistribusi normal karena nilai signifikansinya kurang dari 0,05. Oleh karena itu, pengujian selanjutnya yang dilakukan yaitu menggunakan Wilcoxon Signed Rank Test.

a. Wilcoxon Signed Rank Test pada Debt Equity Ratio

Tabel 5

Hasil Ranks pada Debt Equity Ratio

\begin{tabular}{|c|c|c|c|c|}
\hline \multicolumn{5}{|c|}{ Ranks } \\
\hline & & $\mathrm{N}$ & Mean Rank & Sum of Ranks \\
\hline \multirow[t]{4}{*}{ DER 2020 - DER 2019} & Negative Ranks & $13^{\mathrm{a}}$ & 18.85 & 245.00 \\
\hline & Positive Ranks & $31^{b}$ & 24.03 & 745.00 \\
\hline & Ties & $1^{\mathrm{c}}$ & & \\
\hline & Total & 45 & & \\
\hline \multicolumn{5}{|c|}{ a. DER $2020<$ DER 2019} \\
\hline \multicolumn{5}{|c|}{ b. DER $2020>$ DER 2019} \\
\hline \multicolumn{5}{|c|}{ c. DER 2020 = DER 2019} \\
\hline
\end{tabular}

Berdasarkan tabel di atas, dari 45 jumlah data yang diolah terdapat 13 data yang menunjukkan debt equity ratio tahun $2020<$ debt equity ratio tahun 2019 . Selain itu terdapat 31 data menunjukkan debt equity ratio tahun 2020 > debt equity ratio tahun 2019 dan 1 data yang mempunyai nilai debt equity ratio yang sama.

\section{Tabel 6}

Hasil Test Statistics debt equity ratio

\begin{tabular}{|c|c|}
\hline \multicolumn{2}{|c|}{ Test Statistics $^{\mathrm{a}}$} \\
\hline & $\begin{array}{c}\text { DER 2020 - } \\
\text { DER 2019 }\end{array}$ \\
\hline Z & $-2.918^{\mathrm{b}}$ \\
\hline $\begin{array}{c}\text { Asymp. Sig. (2- } \\
\text { tailed) }\end{array}$ & .004 \\
\hline
\end{tabular}

Berdasarkan tabel di atas, hasil menunjukkan niali z yaitu -2,918 dan nilai Asymp. Sig. (2tailed) yaitu 0,004. Nilai Asymp. Sig. (2-tailed) merupakan nilai sigbnifikansi dari Wilcoxon signed rank test. Nilai signifikansi pada variabel debt equity ratio yaitu 0,0004 yang berarti < dari 0,05 . Oleh karena itu dapat disimpulkan bahwa terdapat perbedaan antara nilai debt equity ratio di tahun 2019 dan tahun 2020 .

b. Hasil Wilcoxon Signed Rank Test pada Total Asset Turnover

Tabel 7

Hasil Rank pada Total Asset Turnover

\begin{tabular}{|l|l|r|r|r|}
\hline \multicolumn{5}{|c|}{ Ranks } \\
\hline \multirow{3}{*}{$\begin{array}{l}\text { TATO 2020 - TATO } \\
2019\end{array}$} & Negative Ranks & $34^{\mathrm{a}}$ & Mean Rank & Sum of Ranks \\
\cline { 2 - 5 } & Positive Ranks & $11^{\mathrm{b}}$ & 14.55 & 875.50 \\
\cline { 2 - 5 } & Ties & $0^{\mathrm{c}}$ & & 159.50 \\
\cline { 2 - 5 } & Total & 45 & & \\
\hline a. TATO 2020 < TATO 2019 & & & \\
\hline b. TATO 2020 > TATO 2019 & & \\
\hline \\
\hline
\end{tabular}


Berdasarkan tabel di atas, dari 45 jumlah data yang diolah terdapat 34 data yang menunjukkan total asset turn over tahun $2020<$ total asset turn over tahun 2019. Selain itu terdapat 11 data menunjukkan total asset turn over tahun 2020 > total asset turn over tahun 2019.

\begin{tabular}{|c|c|}
\hline $\begin{array}{r}\text { Ta } \\
\text { Hasil Test Statistic }\end{array}$ & $\begin{array}{l}8 \\
\text { al asset turn } 0\end{array}$ \\
\hline $\begin{array}{r}\text { Test S } \\
\text { The }\end{array}$ & stics ${ }^{a}$ \\
\hline & \begin{tabular}{|c|} 
TATO $2020-$ \\
TATO 2019 \\
\end{tabular} \\
\hline Z & $-4.041^{\mathrm{b}}$ \\
\hline $\begin{array}{l}\text { Asymp. Sig. (2- } \\
\text { tailed) }\end{array}$ & .000 \\
\hline a. Wilcoxon Sign & Ranks Test \\
\hline b. Based on pos & ranks. \\
\hline
\end{tabular}

Berdasarkan tabel di atas, hasil menunjukkan niali $z$ yaitu $-4,041$ dan nilai Asymp. Sig. (2tailed) yaitu 0,000. Nilai Asymp. Sig. (2-tailed) merupakan nilai signifikansi dari Wilcoxon signed rank test. Nilai signifikansi pada variabel total asset turn over yaitu 0,0000 yang berarti < dari 0,05 . Oleh karena itu dapat disimpulkan bahwa terdapat perbedaan antara nilai total asset turn over di tahun 2019 dan tahun 2020.

c. Hasil Wilcoxon Signed Rank Test pada Return On Equity

Tabel 9

Hasil Wilcoxon Signed Rank Test pada return on equity

\begin{tabular}{|c|c|c|c|c|}
\hline \multicolumn{5}{|c|}{ Ranks } \\
\hline & & $\mathrm{N}$ & $\begin{array}{l}\text { Mean } \\
\text { Rank }\end{array}$ & $\begin{array}{l}\text { Sum of } \\
\text { Ranks }\end{array}$ \\
\hline \multirow[t]{4}{*}{$\begin{array}{l}\text { ROE } 2020 \text { - ROE } \\
2019\end{array}$} & $\begin{array}{l}\text { Negative } \\
\text { Ranks }\end{array}$ & $35^{a}$ & 25.10 & 878.50 \\
\hline & Positive Ranks & $10^{\mathrm{b}}$ & 15.65 & 156.50 \\
\hline & Ties & $0^{c}$ & & \\
\hline & Total & 45 & & \\
\hline \multicolumn{5}{|c|}{ a. ROE $2020<$ ROE 2019} \\
\hline \multicolumn{5}{|c|}{ b. ROE $2020>$ ROE 2019} \\
\hline \multicolumn{5}{|c|}{ c. ROE $2020=$ ROE 2019} \\
\hline
\end{tabular}

Berdasarkan tabel di atas, dari 45 jumlah data yang diolah terdapat 35 data yang menunjukkan return on equity tahun $2020<$ return on equity tahun 2019 . Selain itu terdapat 10 data menunjukkan return on equity tahun 2020 > return on equity tahun 2019.

Tabel 10

Hasil Test Statistic return on equity

\begin{tabular}{|l|r|}
\hline \multicolumn{2}{|c|}{ Test Statistics $^{\mathrm{a}}$} \\
\hline & $\begin{array}{c}\text { ROE 2020 - } \\
\text { ROE 2019 }\end{array}$ \\
\hline$Z$ & $-4.075^{\mathrm{b}}$ \\
\hline $\begin{array}{l}\text { Asymp. Sig. (2- } \\
\text { tailed) }\end{array}$ & .000 \\
\hline a. Wilcoxon Signed Ranks Test \\
\hline \multicolumn{2}{|l}{ b. Based on positive ranks. } \\
\hline
\end{tabular}

Berdasarkan tabel di atas, hasil menunjukkan niali z yaitu $-4,075$ dan nilai Asymp. Sig. (2tailed) yaitu 0,000. Nilai Asymp. Sig. (2-tailed) merupakan nilai signifikansi dari Wilcoxon signed rank test. Nilai signifikansi pada variabel return on equity yaitu 0,0000 yang berarti < 
dari 0,05 . Oleh karena itu dapat disimpulkan bahwa terdapat perbedaan antara nilai return on equity di tahun 2019 dan tahun 2020.

\section{Pembahasan}

Berdasarkan hasil penelitian di atas, keempat variabel penelitian mempunyai hasil yang berbeda. Penelitian ini menguji apakah ada perbedaan kinerja keuangan perusahaan LQ45 pada sebelum pandemi dan pada saat pandemi. Data yang digunakan yaitu laporan keuangan Tahun 2019 yaitu saat belum terjadi pandemi dan laporan keuangan Tahun 2020 pada saat terjadi pandemi. Kinerja keuangan perusahaan yang digunakan untuk mengukur yaitu rasio keuangan. ada empat rasio keuangan yang digunakan yaitu current ratio, debt equity ratio, total asset turnover, dan return on equity. Hasil dari keempat variabel tersebut yatu pada current ratio terdapat perbedaan nilai pada sebelum pandemi tahun 2009 dan pada saat pandemi di tahun 2020. Jika dibandingkan dengan penelitian yang dilakukan oleh (Anugrah et al., n.d.), nilai current ratio tidak ada perbedaan nilai sebelum dan saat terjadinya pandemi pada perusahaan manufaktur.

Tiga rasio keuangan lainnya yaitu debt equity ratio, total asset turnover, dan return on equity ternyata mempunyai hasil uji yang sama. Hasil dari uji data yang dilakukan menunjukkan bahwa terdapat perbedaan nilai dari debt equity ratio, total asset turnover, dan return on equity saat sebelum pandemi di tahun 2019 dan saat terjadi pandemi di tahun 2020. Jika dibandingkan dengan penelitian (Violandani, 2021). Dari ketiga variabel tersebut hanya debt equity ratio yang nilainya tidak terdapat perbedaan antara sebelum dan saat pandemi. Variabel total asset turnover dan return on equity terdapat perbedaan nilai sebelum dan pada saat pandemi.

Variabel current ratio merupakan salah satu rasio untuk mengukur likuiditas perusahaan. Peran rasio likuiditas yaitu mengukur kemampuan perusahaan dalam melunasi kewajiban jangka pendek perusahaan yang segera jatuh tempo. Pada penelitian ini, variabel tersebut menunjukkan data rata-rata di tahun 2019 senilai 1760,33 dan di tahun 2020 senilai 1630,82 . Oleh karena itu ada penurunan nilai current ratio sebesar 129,51 . Hal ini sejalan dengan penelitian Devi et al., (2020) yang menunjukkan adanyaa penurunan signifikan pada rasio likuiditas. ada sedikit penurunan, akan tetapi perusahaan masih bisa dikatakan mampu dalam menutupi kewajiban jangka pendeknya pada saat adanya pandemi walaupun tidak selikuid sebelum adanya pandemi. Dari penjelasan di atas, dapat dikatakan bahwa kinerja keuangan perusahaan LQ45 mayoritas mengalami penurunan.

Variabel debt equity ratio menujukkan salah satu pengukuran kinerja keuangan untuk mengukur solvabiltas perusahaan. Rasio solvabilitas merupakan rasio keuangan yang digunakan untuk mengetahui kemampuan perusahaan dalam pemenuhan kewajibannya Pada uji Wilcoxon signed rank, debt equity ratio menunjukkan data bahwa ada 13 perusahaan yang nilai debt quity rationya pada saat pandemi kurang dari nilai debt equity ratio saat terjadinya pandemi. Ada juga 31 perusahaan yang nilai debt equitynya lebih besar saat pandemi dari pada sebelum pandemi dan satu perusahaan yang nilai debt quitynya sama sebelum dan saat pandemi. Dan kesimpulan dari uji beda tersebut yaitu ada perbedaan antara nilai debt equity ratio sebelum dan saat pandemi. Hal tersebut sejalan dengan penelitian Anugrah et al., (n.d.) yang menyatakan bahwa tidak ada penurunan signifikan pada nilai debt equity ratio sebelum dan saat pandemi. Berarti pada perusahaan LQ45, mayoritas perusahaanya masih bisa mempertahankan nilai debt equity ratio pada saat pandemi mash terjadi di tahun 2020. bahkan bisa lebih besar nilai jika dibandingkan sebelum pandemi. Hal tersebut menjadi kabar baik bagi para kreditor karena mayoritas perusahaan masih bisa memanfaatkan ekuitas yang dimilikinya untuk membayar kewajibannya di tahun 2019 dan tahun 2020. Dari penjelasan di atas, dapat dikatakan bahwa kinerja keuangan perusahaan LQ45 mayoritas mengalami kenaikan.

Variabel total asset turnover menujukkan salah satu pengukuran kinerja keuangan pada rasio aktivitasnya. Rasio aktivitas merupakan rasio yang menunjukkan perusahaan mampu dalam melaksanakan kegiatannya terutama dalam penggunaan asset yang dimiliki secara efektif atau tidak. Pada variabel total asset turnover, dari 45 perusahaan LQ45 ada 34 perusahaan yang mempunyai nilai total asset turnover di tahun 2020 lebih kecil nilainya 
dibandingkan sebelum pandemi. Namun, hasil ini berbeda dengan penelitian Devi et al., (2020) karena hasil penelitiannya menyebutkan ada epningkatan pada rasio aktivitasnya. Ada 11 perusahaan yang nilai total asset turnover di tahun 2020 lebih besar daripada di tahun 2019. Hal ini berarti mayoritas perusahaan yang bergabung di LQ45, pandemic sangat berpengaruh terhadap nilai total asset turnovemya. Total asset turnover merupakan salah satu pengukuran kinerja keuangan pada hal rasio aktivitas. Hal tersebut berarti mayoritas perusahaan belum optimal dalam pengelolaan atau perputaran asset yang dimilikinya pada saat pandemi terjadi di tahun 2020. Perusahaan lain masih dapat mempertahankan pengelolaan dan perputaran asetnya di masa pandemi. Oleh karena itu rasio aktivitas perusahaan ternyata belum bisa dikendalikan oleh perusahaan selama pandemi terjadi. Dari penjelasan di atas, dapat dikatakan bahwa kinerja keuangan perusahaan LQ45 mayoritas mengalami penurunan.

Kemudian untuk variabel return on equity pada penelitian ini salah satu pengukuran untuk mengukur kinerja keuangan perusahaan pada tingkat profitabilitas perusahaan. Rasio profitabilitas digunakan untuk mengukur kemampuan perusahaan dalam mendapatkan keuntungan dengan memperhitungkan aset atau ekuitas. Hasil dari pengujian Wilcoxon signed rank, dari 45 perusahaan yang bergabung di LQ45, terdapat 35 perusahaan yang nilai return on equitynya di tahun 2020 selama pandemi lebih kecil dari sebelum pandemi di tahun 2019. Ada 10 perusahaan yang nilai return on equitynya pada saat pandemi lebih besar daripada sebelum pandemic di tahun 2019. Hasil peneltiian ini sejalan dengan hasil peneitian Kumala et al., (2021) yang menyatakan ada perbedaan yang signifikan pada return on equity selama pandemi. Hal ini berarti adanya pandemi yang terjadi telah mempengaruhi nilai return on equity pada perusahaan. Mayoritas perusahaan yang tergabung dalam LQ45 belum bisa mengoptimalkan kontribusi ekuitas dalam menghasilkan laba yang baik pada saat terjadinya pandemi. Untuk 10 perusahaan lain ternyata masih bisa memanfaatkan ekuitas dengan baik dalam menciptakan keuntungan pada saat pandemi terjadi. Dari penjelasan di atas, dapat dikatakan bahwa kinerja keuangan perusahaan LQ45 mayoritas mengalami penurunan.

\section{SIMPULAN}

Penelitian ini meneliti mengenai perbedaan kinerja keuangan perusahaan yang tergabung pada Indeks LQ45 pada saat sebelum pandemi Covid-19 dan pada saat terjadinya pandemi covid-19. Data yang digunakan yaitu laporan keuangan tahunan di Tahun 2019 dan tahun 2020. Dalam uji beda yang dilakukan pada penelitian ini digunakan dua alat uji yaitu paired sample t-tes dan Wilcoxon signed rank test. Kinerja keuangan perusahaan yang digunkan untuk pengukuran yaitu ada empat rasio yaitu current ratio, debt equity ratio, total asset turnover, dan return on equity sebagai variabel dari penelitian ini.

Hasil pengujian data tersebut menunjukkan bahwa keempat variabel pada penelitian ini terdapat perbedaan nilai dari masing-masing rasio antara sebelum pandemi di tahun 2019 dan saat terjadinya pandemic di tahun 2020. Pada variabel current ratio, terjadi penurunan nilai pada tahun 2020 sehingga masa pandemi sangat mempengaruhi tingkat likuiditasnya atau kemampuan perusahaan dalam melunasi kewajiban jangka pendeknya. Pada variabel debt equity ratio, mayoritas perusahaan mempunyai nilai yang lebih besar pada saat pandemi terjadi di tahun 2020 daripada sebelum terjadinya pandemi di tahun 2019. Oleh karena itu mayoritas perusahaan belum bisa mengoptimalkan pemanfaatan ekuitasnya dengan baik dalam pemenuhan kewajibannya dalam masa pandemi. Untuk variabel total asset turnover, mayoritas perusahaan masih mempunyai nilai yang lebih kecil pada saat pandemi daripada sebelum pandemi. Hal tersebut mempengaruhi tingkat rasio aktivitas perusahaan yang berarti perusahaan belum dapat memaksimalkan pengelolaan dan perputaran asset di saat pandemi. hal tersebut juga terjadi pada variabel return on equity yang berhubungan dengan tingkat profitabilitas perusahaan. Mayoritas perusahaan yang tergabung di Indeks LQ45 nilai return on equitynya saat pandemi terjadi lebih kecil 
daripada sebelum pandemi. oleh karena itu, perusahaan belum bisa memanfaatkan ekuitas dengan baik dalam memperoleh keuntungannya.

\section{REFERENSI}

Anugrah, F., Ekonomi, F., Lampung, U., Prasetyo, T. J., \& Si, M. (n.d.). Penerapan kebijakan WFH bagi beberapa perusahaan terutama untuk perusahaan manufaktur dan transport di Indonesia dinilai dapat merugikan, karena banyak perusahaan yang harus melewati proses birokrasi yang sulit, sehingga beberapa perusahaan harus mengam.

Devi, S., Warasniasih, N. M. S., \& Masdiantini, P. R. (2020). The Impact of COVID-19 Pandemic on the Financial Performance of Firms on the Indonesia Stock Exchange. Journal of Economics, Business, \& Accountancy Ventura, 23(2), 226-242. https://doi.org/10.14414/jebav.v23i2.2313

Kumala, E., Diana, N., \& Mawardi, M. C. (2021). Pengaruh Pandemi Virus Covid-19 Terhadap Laporan Keuangan Triwulan Pada Perusahaan Lq-45 Yang Terdaftar Di Bursa Efek Indonesia. E-Jra, 10(02), 74-83.

Montolalu, C., \& Langi, Y. (2018). Pengaruh Pelatihan Dasar Komputer dan Teknologi Informasi bagi Guru-Guru dengan Uji-T Berpasangan (Paired Sample T-Test). D'CARTESIAN, 7(1), 44. https://doi.org/10.35799/dc.7.1.2018.20113

Munawir, S. (2014). Analisa Laporan Keuangan (Keempat). Liberty.

Nguyen, H. H., Ngo, V. M., \& Tran, A. N. T. (2021). Financial performances, entrepreneurial factors and coping strategy to survive in the COVID-19 pandemic: case of Vietnam. Research in International Business and Finance, 56(August 2020), 101380. https://doi.org/10.1016/j.ribaf.2021.101380

Pinanditha, A. W., \& Suryantini, N. P. S. (2016). Pengaruh Profitabilitas, Rasio Solvabilitas, Ukuran Perusahaan, Dan Reputasi Auditor Terhadap Peringkat Obligasi Pada Sektor Perbankan. E-Jurnal Manajemen Universitas Udayana, 5(10), 6670-6699. https://ojs.unud.ac.id/index.php/Manajemen/article/download/23748/15760

Rababah, A., Al-Haddad, L., Sial, M. S., Chunmei, Z., \& Cherian, J. (2020). Analyzing the effects of COVID-19 pandemic on the financial performance of Chinese listed companies. Journal of Public Affairs, 20(4). https://doi.org/10.1002/pa.2440

Rahayu, N. T., \& Muharam, H. (2021). The Impact of The Covid-19 Pandemic on Provincial Economic Performance in Indonesia. Management Analysis Journal, 10(1), 23-36. https://doi.org/10.15294/maj.v10i1.43950

Rahmani, A. N. (2020). Impact of Covid-19 on Stock Prices and Financial Performance. Kajian Akuntansi, 21(2), 252-269.

Setyaningrum, K. D., Atahau, A. D. R., \& Sakti, I. M. (2020). Analisis Z-Score Dalam Mengukur Kinerja Keuangan Untuk Memprediksi Kebangkrutan Perusahaan Manufaktur Pada Masa Pandemi Covid-19. Jurnal Riset Akuntansi Politala, 3(2), 7487. https://doi.org/10.34128/jra.v3i2.62

Shen, H., Fu, M., Pan, H., Yu, Z., \& Chen, Y. (2020). The Impact of the COVID-19 Pandemic on Firm Performance. Emerging Markets Finance and Trade, 56(10), 2213-2230. https://doi.org/10.1080/1540496X.2020.1785863

Violandani, D. S. (2021). Analisis Komparasi Rasio Keuangan Sebelum Dan Selama Pandemi Covid-19 Pada Perusahaan Terbuka Yang Terdaftar Pada Indeks Lq45. Journal of Chemical Information and Modeling, 53(9), 1689-1699.

Wijayani, D. R. (2017). PENGARUH INTELLECTUAL CAPITAL TERHADAP KINERJA KEUANGAN PERUSAHAAN PUBLIK DI INDONESIA (Studi Empiris Pada Perusahaan Manufaktur di BEI 2012-2014). Jurnal Riset Akuntansi Dan Bisnis Airlangga, 2(1), 97116. https://doi.org/10.31093/jraba.v2i1.23 